\title{
Assessing the Effect of Agrometeorological Indices on Rainfed Rice Crop at Bhubaneswar (Odisha), India
}

\author{
Manoj Kumar Beck ${ }^{1 *}$, Harsh Vardhan Puranik ${ }^{1}$, Gouranga Kar ${ }^{2}$ and Gopi Krishna Das ${ }^{1}$ \\ ${ }^{1}$ Department of Agrometeorology, IGKV, Raipur 492012, Chhattisgarh, India \\ ${ }^{2}$ ICAR-Indian Institute of Water Management, Bhubaneswar, Odisha, India \\ *Corresponding author
}

\section{A B S T R A C T}

\section{Keywords}

Thermal requirement, Heat use efficiency, Rice, agro-climatic indices, Seasons

Article Info

Accepted:

24 July 2020

Available Online:

10 August 2020
Field experiment was conducted in kharif season at research farm of ICARIIWM, Khurdha, Odisha to assess the effect of meteorological indices on rice cv. Lalat under two (2018-19 \& 2019-20) growing seasons. The duration of phenological stages and accumulation of agro-climatic indices (GDD, PTU and HTU) were greatly influenced with different growing season and delay in transplanting. The study revealed that the higher GDD, PTU and HTU were accounted on different growth stages at second growing season. Among the seasons and transplanting dates, the meteorological indices accretion was perceived in $2^{\text {nd }}$ growing season as compared to $1^{\text {st }}$ growing season crop. Second season crop had transplanted earlier and get highest heat use efficiency.

\section{Introduction}

Weather variability and climate change greatly influence the agricultural productivity at all hemisphere. Production and productivity of every crop has its own definite requirements for particular weather condition for its proper growth, development and gaining optimum yield (Razzaq et al., 1986; Zinn et al., 2010). Temperature is one of the most important weather parameters for regulating and controlling the crop growth and development and plays the role in disease and pest infection. The concept of heat units based on the concept that real time required to achieve the phenological stage is linearly related to temperature in the range between base temperature \& optimal temperature. Heat units are considered as the fundamental units used to examine the phenology of crops over climatic variations (Leith, 1974; Sreenivas et al., 2010). Efficiency, utilization of heat in terms of dry matter accretion, depends on crop type, genetic factors \& sowing time and it has great practical application on crop production and productivity (Rao et. al., 1999). Delay in transplanting significantly reduced yield and yield attributes (Singh et al., 2004). Growth and yield performance varied with different growing season due to day-to-day changing weather conditions. Temperature based agro-meteorological 
indices such as growing degree days (GDD) and Heat Use Efficiency (HUE) are quite useful in predicting growth and yield of different crops. Influences on weather situations as well as temperature on phenology and yield of crop plant can be studied under two growing seasons through the accumulated heat unit system (Shankar et. al., 1996). The aim of the present study was to predict pant stages and yield of rice crop using agrometeorological indices in tropical region of Khurdha district of Odisa.

\section{Materials and Methods}

\section{Study area}

The farm experiment was carried out during kharif season (2018 and 2019) at ICARIIWM, Deras, Mendhasal, Khurdha District of Odisha state. Which lies between Latitude $20^{\circ} 17^{\prime} \mathrm{N}$ and, Longitude 85 $41^{\prime} \mathrm{E} ; 23 \mathrm{~m}$ above sea level. The average annual rainfall of study area is $1428 \mathrm{~mm}$. The rainfall receives mainly through south-west monsoon, which is started from end of June to lasts till October. The weather remains little dry from November to June. Summer season is hot humid and sometimes feel mercury crosses $45.5^{\circ} \mathrm{C}$ in the May-June while winter is cool and dry. In this reason the warmest average temperature is $31.3^{0} \mathrm{C}$ and lowest average temperature is $21.8^{0} \mathrm{C}$.

\section{Observations}

The rice crop (cv. Lalat) was transplanted on July 2018 and 2019, respectively on $20 \mathrm{~cm}$ spaced ridges keeping plant-to-plant distance of $10 \mathrm{~cm}$, with a seed rate of $50 \mathrm{~kg} \mathrm{ha}^{-1}$ and $\mathrm{N}: \mathrm{P}: \mathrm{K}$ fertilizer dose of 60:30:30. Dates of major phenological stages viz., emergence, transplanting stage, tillering stage, panicle initiation stage, flowering, milking, dough and maturity stages were recorded from the experimental plots. Weather data were recorded from the Agro-meteorological Observatory, situated near the experimental farm and weather variables namely Tmax, Tmin, SSH, wind speed $(\mathrm{km} / \mathrm{hrs})$, Rainfall, Air Pressure, RH (\%), Soil temperature are recorded daily during growing season 2018 and 2019.

\section{Agro-meteorological Indices}

The different agro-meteorological indices, viz. growing degree days (GDD), heliothermal units (HTU), photo thermal units (PTU), pheno-thermal index (PTI), radiation use efficiency (RUE) and heat use efficiency (HUE) were computed by adopting procedure laid out by Singh et al., 2015.

\section{Growing degree days (GDD)}

The sum of the degree days for the completion of each phenophases were obtained by using the following formula:

$\mathrm{GDD}=\Sigma\left[(\mathrm{Tx}+\mathrm{Tn}) / 2-\mathrm{T}_{\text {base }}\right]$

Where,

Tmax $=$ Daily maximum temperature $\left({ }^{\circ} \mathrm{C}\right)$

Tmin $=$ Daily minimum temperature $\left({ }^{\circ} \mathrm{C}\right)$

Tbase $=$ Minimum threshold/Base temperature $\left({ }^{\circ} \mathrm{C}\right)$

The growing degree days were computed by considering the base temperature of $10{ }^{0} \mathrm{C}$.

\section{Photo thermal Unit (PTU)}

The day and night period is one of the basic factors controlling the period of vegetative growth for photosensitive cultivars. In case of long day plants, the length of night is critical for determining, whether plants will enter into reproductive phase or not. Photo-thermal units are the cumulative value of growing degree days, multiplied by bright sunshine 
hours. This can be mathematically represented by the following formula:

PTU $\left(\right.$ day ${ }^{\circ} \mathrm{C}$ hour $)=$ GDD X N

Where, $\mathrm{N}=$ maximum possible sunshine hour.

\section{Heliothermal Unit (HTU)}

The heliothermal units for a day represent the product of GDD and the hours of bright sunshine for that particular day. The sum of HTU for particular phenophases of interest was determined according to the equation:

HTU $\left(\right.$ day ${ }^{\circ} \mathrm{C}$ hour $)=$ GDD X n

Where, $\mathrm{n}=$ actual bright sunshine hours (n).

\section{Phenothermal index (PTI)}

Phenothermal index the ratio of degree days to the number of days between two phonological stages was calculated was determined according to the equation:

$\operatorname{PTI}\left({ }^{\circ} \mathrm{C}\right)=\mathrm{GDD} / \mathrm{Number}$ of days between two phenological stages.

\section{Radiation use efficiency (RUE)}

The radiation use efficiency is a ratio of biological yield and the radiation intercepted. It can be represented by using the following formula:

RUE $\left(\mathrm{gMJ}^{-1}\right)=$ Biomass $\left(\mathrm{g} / \mathrm{m}^{2}\right) /$ PAR $\left(\mathrm{MJ} / \mathrm{m}^{2} /\right.$ day $)$

Where, PAR is cumulative intercepted photo synthetically active radiation.

Line Quantum sensor was used to measure the amount of intercepted radiant energy (PAR in the range of 380-700 nm) above the crop surface and ground surface keeping the sensor
$5 \mathrm{~cm}$ above the surface. The observations were record at different growth stages. The intercepted PAR (IPAR) was measured following relationship:

$\mathrm{I}_{\mathrm{i}}=\mathrm{I}_{0}-\mathrm{I}_{\mathrm{re}}-\mathrm{I}_{\mathrm{t}}+\mathrm{I}_{\mathrm{rg}}$

$\mathrm{I}_{\mathrm{i}}(\%)$ by the canopy $=\left(\mathrm{I}_{\mathrm{i}} / \mathrm{I}_{0}\right) * 100$

where,

Ii = Intercepted photosynthetic active radiation (PAR) by the canopy

$\mathrm{I} 0=$ Incident PAR on the canopy

Ire $=$ Reflected PAR by the canopy

It $=$ Transmitted PAR through the canopy

Irg $=$ Reflected PAR from the ground.

\section{Heat use efficiency (HUE)}

Heat use efficiency is also represented by thermal time use efficiency (TTUE), which indicates the amount of dry matter produced per unit of growing degree days or thermal time. This was computed by using the following formula:

$$
\operatorname{HUE}\left(\mathrm{g} / \mathrm{m}^{20} \mathrm{C} \text { day }{ }^{-1}\right)=\frac{\text { Biomass }\left(\mathrm{g} / \mathrm{m}^{2}\right)}{\left.-\mathrm{GDD}^{0} \mathrm{C} \text { days }\right)}
$$

Where, GDD is growing degree days.

\section{Results and Discussion}

\section{Accumulated Growing Degree Days (AGDD)}

The accumulated growing degree days (AGDD) to reach various growth stages and showed relative variation among two crop growing seasons which are presented in Table-1. $2^{\text {nd }}$ season (2019) crop higher accumulated of growing degree days at various phenophases $\left(9820^{\circ} \mathrm{C}\right.$ day) whereas, $1^{\text {st }}$ growing season shows less accumulated $\operatorname{GDD}\left(9608^{\circ} \mathrm{C}\right.$ day). Table-1 shows that because crop was transplanted earlier in 
season 2019 as compare to season 2018. So, first season crop phases high temperature an all the phases and thus duration of maturity was shortened.

\section{Accumulated Helio-thermal Units (AHTU)}

The accumulated helio-thermal units (AHTU) accumulated by the crop to attain under different phenophases in both growing seasons are shown in Table-1. The $2^{\text {nd }}$ growing season (2019) crop accumulated highest AHTU $\left(55602^{\circ} \mathrm{C}\right.$ day)whereas, $1^{\text {st }}$ growing season crop less accumulated $\left(46830^{\circ}\right.$ Cday) and the mean accumulated HTU was calculated $51216^{\circ} \mathrm{C}$ day of both crops growing season. Reduction in HTU under late growing season from the normal sowing time indicated that the crop used more heat units under crop sown early rather than later crop growth stages. Similar results were reported by Solanki et al., 2015.

\section{Accumulated Photo-thermal Units (APTU)}

The accumulated photo-thermal units (APTU) showed considerable variation under two growing seasons where, $2^{\text {nd }}$ growing season (2019) crop accumulated highest APTU $\left(117911^{\circ} \mathrm{C}\right.$ day) whereas, 1stgrowing season crop less accumulated $\left(117162^{\circ} \mathrm{C}\right.$ day) and the mean accumulated PTU was calculated $117537{ }^{\circ} \mathrm{C}$ day of both crops growing season. In $2^{\text {nd }}$ season transplanted crop, higher values of agrometeorological indices (GDD, HTU and PTU) were accumulated to attain physiological maturity as compared to $1^{\text {st }}$ season crop sown.

\section{Phenothermal Index (PTI)}

The phenothermal index (PTI) showed least variation under two growing season and the results obtained are presented in Table 1. The $1^{\text {st }}$ growing season (2019) crop Index was highest PTI (158) whereas, $2^{\text {nd }}$ growing season crop was obtained less (156) index. And the mean PTI was calculated 157 Index of both crops growing season.

\section{Radiation Use Efficiency (RUE)}

The most important aspect of crop development affecting the dry matter production that is concerned with the development of leaf canopy and its effect on the efficiency of radiation interception. Radiation use efficiency (RUE) of Rice showed relatively least variations and are presented in Table-2.

RUE at $1^{\text {st }}$ growing season was observed 0.52 , $1.29,1.27,1.33,1.39,1.53 \mathrm{~g} / \mathrm{MJ}$ and second growing season $0.64,1.47,1.55,1.53,1.72$, $1.87 \mathrm{~g} / \mathrm{MJ}$ at $30,45,60,75,90$ and physiological maturity days growth interval respectively. RUE based on biological yield was highest in $2^{\text {nd }}$ growing season (1.46 $\mathrm{g} / \mathrm{MJ})$ whereas lowest in $1^{\text {st }}$ growing season $\left(1.22 \mathrm{~g} / \mathrm{m}^{2} /{ }^{0} \mathrm{C}\right.$ day).

During the reproductive phases of crop growth period was obtained highest RUE in both the crop growing season. RUE arose variation due to the differential in dry matter production in two seasons while intercepting different amount of radiation because of variation in canopy surface and the LAI.

\section{Heat Use Efficiency (HUE)}

The Heat use efficiency (HUE) of rice crop for biomass production under two different growing seasons are presented in Table- 2 . HUE at $1^{\text {st }}$ growing season was observed $0.36,0.58,0.68,0.64,0.59,0.47 \mathrm{~g} / \mathrm{m}^{2} /{ }^{0}$ Cday and second growing season $0.37,0.65,0.71$, $0.66,0.62,0.49 \mathrm{~g} / \mathrm{m}^{2} /{ }^{0}$ Cday at $30,45,60,75$, 90 and physiological maturity days growth interval respectively. 
Table.1 Comparison of AGDD, AHTU, APTU and PTI to attain various phenophases in two growing season 2018-19 \& 2019-20 of rice crop

\begin{tabular}{|c|c|c|c|c|c|c|c|c|c|c|}
\hline Crop season & Sowing & $\begin{array}{c}\text { Emergence } \\
\text { date }\end{array}$ & $\begin{array}{c}\text { Transplanting } \\
\text { date }\end{array}$ & Tillers & $\begin{array}{c}\text { Panicle } \\
\text { initiations }\end{array}$ & Flowering & Milking & Dough & Maturity & Total \\
\hline \multicolumn{11}{|c|}{ AGDD } \\
\hline 2018 & 21 & 139 & 402 & 727 & 1109 & 1504 & 1637 & 1875 & 2194 & 9608 \\
\hline 2019 & 20 & 139 & 315 & 810 & 1189 & 1641 & 1739 & 1868 & 2100 & 9820 \\
\hline Mean & 20 & 139 & 359 & 768 & 1149 & 1572 & 1688 & 1872 & 2147 & 9714 \\
\hline \multicolumn{11}{|c|}{ AHTU } \\
\hline 2018 & 48 & 1098 & 1648 & 4725 & 2329 & 4812 & 10315 & 8252 & 13603 & 46830 \\
\hline 2019 & 57 & 293 & 520 & 2065 & 2021 & 11322 & 11216 & 10368 & 17741 & 55602 \\
\hline Mean & 52 & 695 & 1084 & 3395 & 2175 & 8067 & 10766 & 9310 & 15672 & 51216 \\
\hline \multicolumn{11}{|c|}{ APTU } \\
\hline 2018 & 273 & 1835 & 5306 & 9304 & 14196 & 18496 & 20139 & 21942 & 25670 & 117162 \\
\hline 2019 & 257 & 1840 & 4161 & 10367 & 14501 & 20018 & 20345 & 21857 & 24565 & 117911 \\
\hline Mean & 265 & 1838 & 4734 & 9835 & 14349 & 19257 & 20242 & 21899 & 25118 & 117537 \\
\hline \multicolumn{11}{|c|}{ PTI } \\
\hline 2018 & $\mathbf{0}$ & 23 & 19 & 20 & 19 & 19 & 19 & 19 & 19 & 158 \\
\hline 2019 & $\mathbf{0}$ & 23 & 20 & 19 & 19 & 19 & 19 & 19 & 19 & 156 \\
\hline Mean & $\mathbf{0}$ & 23 & 19 & 19 & 19 & 19 & 19 & 19 & 19 & 157 \\
\hline
\end{tabular}


Table.2 Comparison of Radiation use efficiency (RUE) and Heat use efficiency (HUE) to obtained various growth interval in two growing season 2018-19 \& 2019-20

\begin{tabular}{|c|c|c|c|c|c|c|c|}
\hline Crop season & 30 & 45 & 60 & 75 & 90 & Maturity & Mean \\
\hline \multicolumn{8}{|c|}{ RUE (g/MJ) } \\
\hline 2018 & 0.52 & 1.29 & 1.27 & 1.33 & 1.39 & 1.53 & 1.22 \\
\hline 2019 & 0.64 & 1.47 & 1.55 & 1.53 & 1.72 & 1.87 & 1.46 \\
\hline Mean & 0.58 & 1.38 & 1.41 & 1.43 & 1.55 & 1.70 & \\
\hline \multicolumn{8}{|c|}{ HUE $\left(\mathrm{g} / \mathrm{m}^{2} /^{0} \mathrm{Cday}\right)$} \\
\hline 2018 & 0.36 & 0.58 & 0.68 & 0.64 & 0.59 & 0.47 & 0.55 \\
\hline 2019 & 0.37 & 0.65 & 0.71 & 0.66 & 0.62 & 0.49 & 0.58 \\
\hline Mean & 0.37 & 0.62 & 0.69 & 0.65 & 0.60 & 0.48 & \\
\hline
\end{tabular}

The highest mean $\left(0.58 \mathrm{~g} / \mathrm{m}^{2} /{ }^{0}\right.$ Cday) HUE for dry matter production in $2^{\text {nd }}$ growing season whereas, low mean $\left(0.55 \mathrm{~g} / \mathrm{m}^{2} /{ }^{0}\right.$ Cday) HUE in $1^{\text {st }}$ growing season was obtained. Among these two growing seasons the reproductive phases of the crop reported highest HUE due to the high LAI and highest photosynthetic rate in this growth period. It means that the early sown crop used heat, more deficiency as compare to late sown crop. The early sown crop has highest heat use efficiency and it decreased with delay in sowing (Keerthi et al., 2016).

The present study indicated that the timely sowing played important role in determining the arrival of different phenological stages and grain yield. The timely crop sowing took higher thermal times as compared to delayed sowing. The heat units viz. accumulated growing degree days, photo thermal unit, helio thermal unit, radiation use efficiency and heat use efficiency were recorded highest in crop sown on second season as compared to first season. It can be concluded that variability on weather parameter occurs from one season to another season which affect the production and productivity of crop.

\section{References}

Keerthi, P., Pannu, R.K., Singh, R. and Dhaka, A.K., 2016. Thermal requirements, heat use efficiency and plant responses of Indian mustard (Brassica juncea L.) for different levels of nitrogen under different environments. Journal of Agrometeorology, 18(2): 201-205.

Leith, H., 1974. Phenology and seasonality modeling. - Springer, NY,: 3-15.

Rao, VUM, Singh, D. and Singh, R., 1999. Heat use efficiency of winter crops in Haryana. Journal of Agrometeorology, 1: 143-148.

Razzaq, A., Shah, P., Khan, S. B., Saeed, K. and Mohammad, D., 1986. Effect of planting time on the growth and straw yield of wheat varieties. Sarhad Journal of Agriculture,2: 327-334.

Singh, T., Shivay, Y. S. and Singh, S., 2004. Effect of date of transplanting and nitrogen on productivity and nitrogen use indices in hybridand non-hybrid aromatic rice. Acta Agronomica Hungarica, 52(3): 245-252.

Singh, M., Niwas, R., Godara, A. K. and Khichar, M. L., 2015. Pheno-thermal response of plum genotypes in semi arid region of Haryana. Journal of Agrometeorology, 17(2): 230-233.

Solanki, N. S. and Mundra, S. L., 2015. Phenology and productivity of mustard (Brassica juncea L.) under varying sowing environments and irrigation levels. Annals of Agricultural Research 
New Series, 36: 312-317.

Sreenivas, G., Reddy, M. D. and Reddy, D. R., 2010. Agrometeorological indices in relation to phenology of aerobic rice. Journal of Agrometeorology,12(2): 241244.

Shankar, U., K. k. Agrawal and V. K. Gupta, 1996. Heat unit requirements of rainfed soybean, Indian. Journal of Agricultural Sciences, 66: 401-404.

Zinn, K. K., Tunc-ozdemir, M. and Harper, J. F., 2010. Temperature stress and plant sexual reproduction: uncovering the weakest links. Journal of Environmental and Experimental Botany, 61: 19591968.

\section{How to cite this article:}

Manoj Kumar Beck, Harsh Vardhan Puranik, Gouranga Kar and Gopi Krishna Das. 2020. Assessing the Effect of Agrometeorological Indices on Rainfed Rice Crop at Bhubaneswar (Odisha), India. Int.J.Curr.Microbiol.App.Sci. 9(08): 3125-3131. doi: https://doi.org/10.20546/ijcmas.2020.908.355 